\title{
FOOD TECHNOLOGIES
}

DOI https://doi.org/10.30525/978-9934-588-79-2-2.16

\section{ІННОВАЦЙНИЙ ЗАДУМ ТЕХНОЛОГІЇ МАРМЕЛАДУ ЖЕЛЕЙНО-ФРУКТОВОГО З ВИКОРИСТАННЯМ ПЛОДОВО-ОВОЧЕВИХ КРІОДОБАВОК}

\begin{abstract}
Артамонова М. В.
кандидат технічних наук, доцент кафедри технології хліба, кондитерських, макаронних виробів та харчоконцентратів Харківського державного університету харчування та торгівлі

Шматченко Н. В. кандидат технічних наук, старший викладач кафедри технології хліба, кондитерських, макаронних виробів та харчоконцентратів Харківського державного університету харчування та торгівлі м. Харків, Україна

В сучасних економічних умовах на ринку підприємствам необхідно постійно удосконалювати існуючі товари, технології виробництва, методи їх реалізації, впроваджувати технічні нововведення, розробляти нові товари і виводити їх на ринок [1].

Ознакою інновації $є$ вимога, щоб продукт, процес, метод тощо був для підприємства новим або значно вдосконаленим. До інновацій належать продукти, процеси або методи, які підприємство створило першим. Також ознакою інновації $\epsilon$ те, що продукт, процес, метод маркетингу або організації повинен бути впроваджений. Новий або вдосконалений продукт є впровадженим, коли він реалізується на ринку [2, с. 10].

Тому сьогодні основними задачами харчової промисловості $\epsilon$ : створення продуктів оздоровчої дії, нові технології виготовлення продуктів харчування, відновлення та використання харчових відходів, забезпечення біобезпеки пакувальних матеріалів тощо. Перед виробниками стоїть завдання приділяти підвищену увагу харчовим продуктам, які відповідають потребам споживачів у здоровому способі життя. Як наслідок, існує необхідність впроваджувати інновації у 64
\end{abstract}


технологіях харчових продуктів та переробці сировини, щоб витримати конкуренцію серед виробників [3].

Для створення на ринку безпечних високоякісних продуктів, що сприяють зміцненню здоров'я пропонуються можливості використання технології нетеплової обробки. Інноваційна кріогенна переробка харчових продуктів часто сприймається як альтернатива термічній обробці. У проведених в роботі дослідженнях приділяється увага поліпшенню функціональних можливостей продуктів харчування завдяки мінімальній обробці свіжої рослинної сировини, її якості, безпеки і зручності у використанні. Особливий інтерес представляють дослідження, присвячені «шляху до комерціалізації» для обраних нових технологій з використанням рослинних добавок, отриманих за кріотехнологіями [4].

Інноваційна стратегія даного дослідження передбачає:

- удосконалення технології мармеладу желейно-фруктового 3 використанням рослинних кріодобавок, яка має певні конкурентні переваги перед традиційними технологіями в цьому сегменті;

- пропозицію продуктів для розширення асортименту желейних виробів без використання синтетичних добавок (ароматизаторів, есенцій, барвників);

- створення нових видів мармеладу на пектині з підвищеним вмістом біологічно активних речовин.

Ураховуючи вищенаведену інформацію, було складено характеристику інноваційного продукту (табл. 1).

Таблиця 1

\section{Інноваційний задум нового продукту - мармеладу} желейно-фруктового $з$ використанням плодово-овочевих кріодобавок

\begin{tabular}{|l|l|l|}
\hline $\begin{array}{c}\text { Найменування } \\
\text { показника }\end{array}$ & \multicolumn{1}{|c|}{ Характеристика } & \multicolumn{1}{c|}{ Джерела реалізації } \\
\hline \multicolumn{1}{|c|}{$\mathbf{2}$} & \multicolumn{1}{|c|}{$\mathbf{2}$} & \multicolumn{1}{c|}{$\mathbf{3}$} \\
\hline $\begin{array}{l}\text { Зовнішній } \\
\text { вигляд продукту }\end{array}$ & $\begin{array}{l}\text { Мармелад правильної } \\
\text { форми з ясним малюн- } \\
\text { ком і чіткими контурами, } \\
\text { без деформації. Поверхня } \\
\text { рівномірно обсипана } \\
\text { цукром білим }\end{array}$ & $\begin{array}{l}\text { Досягається за рахунок } \\
\text { дотримання раціональних } \\
\text { параметрів технологічного } \\
\text { процесу та використання } \\
\text { драглеутворювача, кріопаст } \\
\text { і кріопорошків }\end{array}$ \\
\hline $\begin{array}{l}\text { Цільовий } \\
\text { сегмент }\end{array}$ & $\begin{array}{l}\text { Продукт призначений до } \\
\text { споживання широким } \\
\text { верствам населення }\end{array}$ & $\begin{array}{l}\text { В2С: широкі верстви насе- } \\
\text { лення через підприємства } \\
\text { оптової та роздрібної торгівлі }\end{array}$ \\
\hline
\end{tabular}


Продовження таблиці 1

\begin{tabular}{|c|c|c|}
\hline 1 & 2 & 3 \\
\hline $\begin{array}{l}\text { Конкурентні } \\
\text { переваги }\end{array}$ & $\begin{array}{l}\text { Мармелад з рослинними } \\
\text { кріопастами та кріопо- } \\
\text { рошками характеризу- } \\
\text { ється підвищеним вміс- } \\
\text { том вітаміну С, } \\
\beta \text {-каротину, антоціано- } \\
\text { вих, пектинових речовин } \\
\text { та зниженням рецептур- } \\
\text { ної кількості драглеутво- } \\
\text { рювача, лимонної кисло- } \\
\text { ти та цукру }\end{array}$ & $\begin{array}{l}\text { Досягається за рахунок } \\
\text { реалізації технологічних } \\
\text { властивостей рослинних } \\
\text { кріодобавок }\end{array}$ \\
\hline Пакування & $\begin{array}{l}\text { Передбачається пакуван- } \\
\text { ня в паперово-картонні, } \\
\text { полімерні та поліетиле- } \\
\text { нові матеріали }\end{array}$ & $\begin{array}{l}\text { Маса продукту від } 200 \text { г } \\
\text { до } 7 \text { кг залежно } \\
\text { від форми реалізації }\end{array}$ \\
\hline Асортимент & $\begin{array}{l}\text { Асортимент залежить від } \\
\text { виду кріопасти або кріо- } \\
\text { порошку, які додаються }\end{array}$ & $\begin{array}{l}\text { Формування асортименту } \\
\text { здійснюється з урахуван- } \\
\text { ням: технологічного приз- } \\
\text { начення, форми реалізації } \\
\text { та попиту }\end{array}$ \\
\hline $\begin{array}{l}\text { Термін } \\
\text { зберігання }\end{array}$ & 3 місяці & $\begin{array}{l}\text { Умови зберігання мармела- } \\
\text { ду: у сухих, чистих, добре } \\
\text { вентильованих складах за } \\
\text { температури повітря від } \\
15 \text { до } 18^{\circ} \mathrm{C} \text { і відносної воло- } \\
\text { гості повітря не більше } 75 \text { \% }\end{array}$ \\
\hline $\begin{array}{l}\text { Прогнозована } \\
\text { оптова ціна } \\
\text { за } 1 \text { кг }\end{array}$ & до 75 грн & $\begin{array}{l}\text { Досягається за рахунок } \\
\text { використання кріодобавок } \\
\text { та залежить від вартості } \\
\text { сировини }\end{array}$ \\
\hline
\end{tabular}

Реалізація інноваційного задуму потребує формалізації технології у вигляді моделі виробництва мармеладу желейно-фруктового з використанням рослинних кріопаст і кріопорошків (рис. 1).

В межах моделі технологічної системи виробництва мармеладу желейно-фруктового відокремлено окремі підсистеми (А, В, С) та встановлено функціональні зв'язки між ними, конкретні параметри яких потребують обгрунтування. 


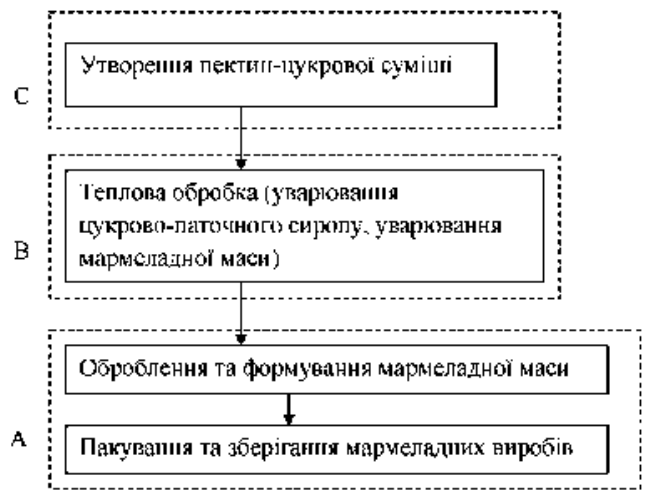

\section{Рис. 1. Модель технологічної системи виробництва мармеладу желейно-фруктового 3 використанням рослинних кріодобавок}

Таким чином, нами було визначено інноваційний задум щодо розширення асортименту мармеладу желейно-фруктового підвищеної харчової цінності з використанням плодово-овочевих кріопаст та кріопорошків. Використання інноваційних розробок у даному продукті дає можливість збільшити продуктивність та поліпшити якість виробленої продукції.

\section{Література:}

1. Скопенко Н. С. Інноваційний розвиток хлібопекарської галузі України: основні напрями, проблеми, ризики / Н. С. Скопенко // Вicник Національного університету «Львівська політехніка». - 2010. № 684 : Проблеми економіки та управління. - С. 66-71.

2. Чорна Н. П. Інноваційний розвиток сфери виробництва продуктів харчування та ризики продовольчої безпеки : монографія / Н. П. Чорна. - Львів : Ліга-Прес, 2012. - 296 с.

3. Galanakis Ch. Innovation Strategies in the Food Industry 1st Edition // Academic Press, 2016. 334 p.

4. Tokusoglu O. Introduction to Innovative Food Processing and Technology // Natural Science and Discovery. 2015. Vol. 1(4). P. 85-87. 